\title{
PENDIDIKAN KARAKTER DI SEKOLAH DASAR NEGERI BRENGOSAN 1 KECAMATAN NGAGLIK KABUPATEN SLEMAN
}

\author{
Oleh: \\ Intan Kusumawati, Yudy Kriswanto \\ Universitas Cokroaminoto Yogyakarta
}

\begin{abstract}
Abstrak
Penelitian ini bertujuan untuk meningkatkan pendidikan karakter siswa kelas V SD N Brengosan 1 Kecamatan Ngaglik Kabupaten Sleman Yogyakarta. Peneliti melakukan penelitian tersebut sejak bulan Mei 2012. Penelitian ini menggunakan penelitian deskriptif yaitu penelitian yang tujuannya untuk menyajikan gambaran lengkap mengenai suatu fenomena atau kenyataan sosial, dengan jalan mendiskripsikan sejumlah variabel yang berkenaan dengan masalah dan unit yang diteliti antara fenomena yang diuji. Populasi dan sampel dalam penelitian ini adalah guru berjumlah 9 orang, karyawan berjumlah 4 orang dan siswa-siswi SD N Brengosan 1 kelas V (Lima) sebanyak 25 siswa. Tehnik yang digunakan dalam penarikan sampel adalah dengan lembar kuesioner. Sedang pengumpulan data di lakukan dengan cara (1) Metode Angket (2) Observasi (3) Metode wawancara, (4) Metode Dokumentasi, (5) Pengukuran dengan Skala Linkert. Data dari hasil penelitian dianalisis secara deskriptif. Dari hasil penelitian menunjukan bahwa pendidikan karakter siswa-siswi kelas V (Lima) di SD N Brengosan 1 mengalami peningkatan, buktinya religiusitas warga sekolah semakin membaik dengan persentase $64 \%$, kejujuran peserta didik yang juga mulai terlihat dengan tidak adanya suatu tindakan sebagai contoh mencontek pekerjaan teman yang mencapai $56 \%$, sikap toleransi $64 \%$, kedisiplinan $72 \%$, kerja keras $72 \%$, kreatif $68 \%$, mandiri $68 \%$, demokratis, 64\%, rasa ingin tahu $68 \%$, semangat kebangsaan $64 \%$, cinta tanah air $64 \%$, menghargai prestasi $72 \%$, bersahabat/komunikatif $60 \%$, cinta damai $76 \%$, gemar membaca $76 \%$, peduli lingkungan $76 \%$, peduli sosial $80 \%$, tanggung jawab 84\%, serta prestasi siswa-siswi SD N Brengosan 1 dari tahun ke tahun baik prestasi akademik maupun non akademik.
\end{abstract}

Kata kunci : pendidikan karakter sekolah dasar

\section{Pendahuluan}

Pendidikan di Indonesia lebih menekankan pada penguasaan materi dalam kurikulum dan lebih mementingkan daya serap atau hafalan dari anak. Praktik ini tergambar jelas dalam model soal ujian atau tes-tes tertentu. Paradigma pendidikan karakter semestinya tidaklah seperti pembelajaran sains yang memang memerlukan ketajaman analisis intelektual. Paradigma pendidikan karakter menghendaki adanya pola-pola internalisasi nilai melalui pembiasaan dan keteladanan. Walaupun sukses di bidang akademis namun mereka belum lulus di bidang akhlak 
dan moralitas. Salah satu mekanisme belajar anak yang paling kuat dalam membentuk karakter anak didik adalah perilaku imitasi, yaitu anak-anak cenderung meniru perilaku dewasa. Perilaku positif yang ditunjukkan orang dewasa akan menghasilkan perilaku positif pada anak, demikian sebaliknya. Akhlak adalah sikap yang melekat pada diri seseorang secara spontan diwujudkan dalam tingkahlaku atau perbuatan. Berbeda dengan etika, etika adalah sebuah tatanan perilaku berdasarkan suatu sistem tata nilai suatu masyarakat tertentu, etika lebih banyak dikaitkan dengan ilmu atau filsafat, karena itu yang menjadi standar baik dan buruk itu adalah akal manusia. Menurut Novan Ardy Wiyani, (2010: 51) Pembentukan karakter sebaiknya ditetapkan sejak usia kanak-kanak atau yang disebut para ahli psikologi sebagai usia emas ( Golden Age ). Asumsinya, pada usia tersebut terbukti sangat menentukan kemampuan anak dalam mengembangkan potensi yang dimilikinya. Hasil penelitian menunjukkan sekitar 50\% variabilitas kecerdasan orang dewasa telah terbangun ketika anak berusia 4 tahun. Peningkatan $30 \%$ berikutnya terjadi pada usia 8 tahun, dan $20 \%$ sisanya pada pertengahan atau akhir dasawarsa kedua. Anak sekolah dasar mengalami perkembangan fisik dan motorik tak terkecuali perkembangan kepribadian, watak emosional, intelektual, bahasa, budi pekerti, dan moralnya yang bertumbuh pesat. Oleh karena itu jika menghendaki pendidikan karakter dapat berhasil maka pelaksanaanya harus dimulai sejak masa kanak-kanak dan Sekolah Dasar (Sigit Dwi K, 2007: 121). Banyaknya tindakan amoral yang dilakukan peserta didik seperti mencontek, membolos, dan tindakan lainya mengindikasikan bahwa pendidikan formal gagal dalam membentuk karakter peserta didik. Berangkat dari hal tersebut diatas, secara formal upaya menyiapkan kondisi, sarana/prasarana, kegiatan, pendidikan, dan kurikulum yang mengarah kepada pembentukan watak dan pendidikan karakter generasi muda bangsa memiliki landasan yuridis yang kuat. Namun, sinyal tersebut baru disadari ketika terjadi krisis akhlak yang menerpa semua lapisan masyarakat, tidak terkecuali juga pada anak-anak usia sekolah. Untuk mencegah lebih parahnya krisis akhlak, kini upaya tersebut mulai dirintis melalui pendidikan karakter bangsa. Dalam pemberian pendidikan karakter bangsa di sekolah, para pakar berbeda pendapat. Setidaknya ada tiga pendapat yang berkembang yaitu ; Pertama, bahwa pendidikan karakter bangsa diberikan berdiri sendiri sebagai suatu mata pelajaran. Pendapat kedua, pendidikan karakter bangsa diberikan secara terintegrasi dalam mata pelajaran PKn, pendidikan agama, dan mata pelajaran lain yang relevan. Pendapat ketiga, pendidikan karakter bangsa terintegrasi ke dalam semua mata pelajaran (Samsuri, 2011: 20). Pendidikan karakter kini memang menjadi 
misi utama pendidikan. Selain menjadi bagian dari proses pembentukan akhlak anak bangsa, pendidikan karakter ini pun diharapkan mampu menjadi pondasi utama dalam meningkatkan derajat dan martabat bangsa indonesia. Di lingkungan Kemdiknas, pendidikan karakter menjadi fokus pendidikan diseluruh jenjang pendidikan yang dibinanya. Pembentukan karakter itu dimulai dari fitrah yang diberikan Tuhan yang kemudian membentuk jati diri dan perilaku.

Menanamkan kejujuran bagi para peserta didik sejak dini tentu saja dapat dilakukan saat mereka masih sekolah dasar dinilai menjadi wadah utama dalam pembentukan karakter. Membentuk karakter jujur pada peserta didik tidak dapat dilakukan dengan cara instan, perlu proses yang panjang dan konsisten agar bisa menanamkan sifat jujur sehingga sikap tersebut mampu benar-benar menjadi karakter setiap peserta didik (Isna, 2011: 48). Bersamaan dengan perubahan yang dihadapi bangsa Indonesia pada era dan pasca reformasi muncul juga tuntutan globalisasi yang semakin merusak dan menerpa dengan keras terhadap seluruh aspek kehidupan, kondisi ini menuntut untuk segera diantisipasi oleh bangsa Indonesia dengan mempersiapkan tenaga pembangunan yang tangguh dan berwawasan global. Globalisasi sebagai akibat berkembangnya teknologi informasi merupakan salah satu karakteristik abad 21 yang sangat signifikan, sehingga butuh perubahan pembaharuan global, sebab sampai saat ini permasalahan berkaitan dengan pendidikan di Indonesia sebagai akibat negatif perubahan global melahirkan situasi yang tidak kondusif. Kondisi tersebut tidak terjadi dikalangan anak sekolah, yang sebenarnya mereka adalah aktor utama pelanjut keberlangsungan negara. Proses pendidikan yang selama ini mereka peroleh belum bisa membangun kesadaran untuk menjadi pelanjut bangsa ini.

Dalam proses pendidikan pelajar wajib digiring menjadi taat hukum yang dimulai dari lembaga keluarga oleh orang tua, di masyarakat serta melalui pendidikan formal di sekolah yakni dengan membangun kesadaran tanggung jawab terhadap hak dan kewajiban asasi individu secara amanah, penyayang dan adil dalam memelihara hubungan harmonis dengan alam, memperkaya warisan budaya dengan setia mengikuti dan mempertahankan, nilai agama yang dianut, teguh politik, kukuh ekonomi, melazimkan musyawarah dengan disiplin dan bijak memilih prioritas pada yang hak sebagai nilai kebenaran. Lembaga pendidikan sebagai pranata sosial bertujuan menggerakkan segala dimensi kehidupan kemanusiaan di segala sektor, sosial, ekonomi, budaya, ilmu pengetahuan, teknologi, politik dan agama. Dalam proses pembelajaran berdasarkan Undang-Undang Sistem Pendidikan Nasional Nomor 20 Tahun 2003; Terdapat empat faktor yang mendukung mengapa pendidikan karakter dibutuhkan. Pertama melalui pemberian 
wewenang penuh terhadap satuan pendidikan ( sekolah ) yang didalamnya terdapat unsur guru sebagai pelaku utama pendidikan, diharapkan guru dapat lebih mengembangkan dan memberdayakan diri untuk mengembangkan potensi dan dimensi peserta didik agar mampu hidup bermasyarakat. Kedua, tujuan pendidikan nasional sangat memberi perhatian dan menitik beratkan pada penanaman dan pembinaan aspek keimanan dan ketaqwaan. Hal ini sebagai isyarat bahwa pengembangan karakter bangsa bersumber dari kesadaran beragama, artinya input, proses dan output pendidikan harus berasal dan bermuara pada penguatan nilai-nilai ketuhanan yang dilandasi keyakinan dan kasadaran penuh sesuai agama yang diyakininya masing-masing. Ketiga, strategi pengembangan kurikulum pendidikan dasar adalah penekanan pada 4 pilar pendidikan yang ditetapkan UNESCO, yaitu belajar mengetahui (learning to know), menjadi dirinya sendiri (learning to be), belajar bekerja (learning to do) dan belajar hidup bersama ( learning to live together), (Kemendikbud; 2010: 6). Pendidikan budi pekerti adalah usaha sadar yang dilakukan dalam rangka menananmkan atau menginternalisasikan nilai-nilai moral kedalam sikap dan perilaku peserta didik agar memiliki sikap dan perilaku yang luhur (berahklakul karimah) dalam kegiatan sehari-hari, baik saat beinteraksi dengan Tuhan, dengan sesama manusia maupun dengan alam/lingkungan. Tujuan pendidikan budi pekerti adalah menguatkan dan mengembangkan nilai-nilai yang dianggap penting, membentuk watak yakni mengembangkan tabi'at anak didik, agar tabi'at dapat berkembang maka perlu diberi fasilitas dan diarahkan. Pendidikan karakter merupakan usaha sadar dan terencana untuk mewujudkan suasana belajar dan proses pembelajaran agar peserta didik secara aktif mengembangkan potensi dirinya untuk memiliki kepribadian, ahklak mulia, dan budi pekerti sehingga karakter ini terbentuk dan menjadi ciri khas peserta didik tersebut.

Dalam pendidikan karakter, terdapat enam nilai etik utama seperti yang tertuang dalam deklarasi Aspen yaitu meliputi (1) dapat dipercaya (trustworthy) seperti sifat jujur (honesty) dan integritas (intregrity),(2) merperlakukan orang lain dengan hormat (treat people with respect), (3) bertanggungjawab (responsible), (4) adil (fair), (5) kasih sayang (caring ), (6) warga Negara yang baik ( good citizen ), (Kemendiknas; 2009: 37). Pendidikan karakter di sekolah merupakan kebutuhan vital agar generasi penerus dapat dibekali dengan kemampuan-kemampuan dasar yang tidak saja mampu menjadikannya lifelong learners sebagai salah satu karakter penting untuk hidup diera informasi yang bersifat global, tetapi juga berfungsi dengan peran serta yang positif baik sebagai pribadi, sebagai anggota keluarga, sebagai warga Negara, maupun dunia. 
Pentingnya membangun karakter bangsa diperlukan suatu keseimbangan karena itu Ki Hadjar Dewantara (2011: 40) mengemukakan bahwa, ',..Pendidikan merupakan daya upaya untuk memajukan bertumbuhnya budi pekerti (kekuatan batin, karakter), pikiran dan tubuh anak. Bagian-bagian itu tidak boleh dipisahkan agar kita dapat memajukan kesempurnaan hidup anakanak. (Kemendiknas, 2011: 40). Salah satu lembaga formal yang saat ini mulai memberikan perhatian lebih terhadap pendidikan karakter terhadap peserta didiknya adalah SD N Brengosan 1, di karenakan adanya berbagai persoalan yang dialami peserta didik berkaitan dengan karakter. SD N Brengosan 1 juga menyadari bahwa selayaknya siswa-siswi sekolah dasar wajib diberikan pendidikan karakter. SD N Brengosan 1 merasa perlu adanya pendidikan karakter terhadap peserta didiknya. Untuk bisa meningkatkan perananya dalam pendidikan karakter terhadap siswa, tentunya memerlukan kerjasama yang ekstra dari tenaga pendidik dan tenaga kependidikan disekolah. Sehingga beberapa upaya yang dilakukan dalam rangka pelaksanaan pendidikan karakter dapat terencana dengan sistimatis, dan dapat mewujudkan karakter pada diri siswa sesuai dengan yang diharapkan.

\section{Metode Penelitian}

Penelitian ini merupakan penelitian deskriptif yaitu penelitian yang berusaha mendiskripsikan suatu gejala, peristiwa, kejadian yang terjadi pada saat sekarang (Sujana dan Ibrahim, 1989: 65). Penelitian deskriptif memusatkan perhatian kepada pemecahan masalahmasalah aktual sebagaimana adannya pada saat penelitian dilaksanakan. Penelitian ini dilaksanakan di Sekolah Dasar Negeri Brengosan 1 di Kabupaten Sleman, Kecamatan Ngaglik, yaitu pada bulan Mei sampai dengan bulan Juli 2012.

Matrik Kegiatan Penelitian Tahun Pelajaran 2012/2013

\begin{tabular}{|l|l|l|l|l|l|l|l|l|l|l|l|l|}
\hline \multirow{2}{*}{} & \multicolumn{9}{|c|}{ Uraian } & \multicolumn{9}{|c|}{ Bulan Megiatan \& bulan } \\
\cline { 2 - 14 } & M 1 & M 2 & M 3 & M 4 & M 1 & M 2 & M3 & M4 & M1 & M2 & M3 & M4 \\
\hline Pengajuan judul & & & X & & & & & & & & & \\
\hline Penyusunan proposal & & & & X & & & & & & & & \\
\hline $\begin{array}{l}\text { Pelaksanaan } \\
\text { Penelitian }\end{array}$ & & & & & & & X & & & & & \\
\hline Penulisan & & & & & & & & X & & & & \\
\hline Pengetikan & & & & & & & & & X & & & \\
\hline Hasil penelitian & & & & & & & & & & & X & \\
\hline
\end{tabular}


Sebagai populasi adalah Siswa-siswi, kepala sekolah, guru dan semuakaryawan di SD Negeri Brengosan 1, yaitu kelas V ( Lima) dengan jumlah 25 Siswa, 9 guru dan 4 karyawan honorer. Adapun metode pengumpulan data yang digunakan dalam penelitian ini adalah :

a. Metode Angket. Teknik ini memberikan tanggung jawab kepada responden untuk membaca dan menjawab pertanyaan. Jenis angket tertutup (angket terstruktur), responden tinggal memberi tanda atau memilih jawaban yang telah disediakan, sedangkan angket terbuka (angket takberstruktur), responden mendapatkan kebebasan untuk menjawab dengan urutan singkat.

b. Observasi. Objek yang diamati adalah nilai-nilai pendidikan karakter, berdasarkan penelitian tersebut indikator pendidikan karakter sebagai berikut : (1) religius, (2) jujur, (3) toleransi, (4) disiplin, (5) kerja keras, (6) kreatif, (7) mandiri, (8) demokratis, (9) rasa ingin tahu, (10) semangat kebangsaan, (11) cinta tanah air, (12) menghargai prestasi, (13) bersahabat/komunikatif, (14) cinta damai, (15) gemar membaca, (16) peduli lingkungan, (17) peduli sosial, (18) tanggung jawab.

c. Metode Wawancara. Teknik wawancara dilakukan jika peneliti memerlukan komunikasi atau hubungan langsung dengan responden, yaitu :

1. Dilakukan terhadap Kepala Sekolah, Guru, dan Siswa.

2. Notulen wawancara.

3. Hasil wawancara, dll.

Dari hasil wawancara tersebut, bisa ditarik kesimpulan tentang nilai-nilai pendidikan karakter anak.

d. Metode Dokumentasi. Keuntungan menggunakan dokumentasi adalah biaya relatif murah, waktu dan tenaga lebih efisien. Kelemahannya adalah data yang diambil dari dokumen cenderung sudah lama. Data yang dikumpulkan dengan teknik dokumentasi cenderung merupakan data sekunder, sedangkan data yang dikumpulkan dengan teknik observasi, wawancara, dan angket cenderung merupakan data primer atau data yang langsung diperoleh dari pihak pertama. Dokumen yang perlukan misalnya : absensi siswa, absensi guru, daftar hadir, dll.

e. Pengukuran dengan Skala Linkert. Metode ini yang paling banyak digunakan ini dikembangkan oleh Lensis Linkert sehingga dikenal dengan nama Skala Linkert. 


\section{Hasil Penelitian danPembahasan}

Responden dalam penelitian ini adalah 25 siswa-siswi , 9 guru dan 4 karyawan SD N Brengosan 1 sebanyak 38 orang. Terdapat dua karakteristik responden yang dimasukkan dalam penelitian ini yaitu : jenis pendidikan, jenis kelamin dan usia.

\section{Jenis pendidikan}

Jumlah responden berdasarkan jenis pendidikan terdiri atas, S1 sebanyak 7 responden, DII sebanyak 4 responden dan 2 responden SLTA,

Jenis pendidikan Guru dan Karyawan

\begin{tabular}{|l|c|c|}
\hline \multicolumn{1}{|c|}{ Jenis pendidikan } & Jenis responden (orang) & Persentase (\%) \\
\hline S1 & 7 & $53,9 \%$ \\
\hline DIII & 0 & $0 \%$ \\
\hline DII & 4 & $30,8 \%$ \\
\hline SLTA & 2 & $15,3 \%$ \\
\hline Total & $\mathbf{1 3}$ & $\mathbf{1 0 0 \%}$ \\
\hline
\end{tabular}

Sumber : data primer yang diolah

2. Jenis kelamin

Jumlah responden berdasarkan jenis kelamin, terdiri atas responden pria 14 responden atau $56 \%$ dan responden wanita sebanyak 11 responden atau $44 \%$

Jenis kelamin Siswa

\begin{tabular}{|l|c|c|}
\hline \multicolumn{1}{|c|}{ Jenis Kelamin } & Jenis responden (orang) & Persentase (\%) \\
\hline Pria & 14 & $56 \%$ \\
\hline Wanita & 11 & $44 \%$ \\
\hline Total & 25 & $100 \%$ \\
\hline
\end{tabular}

Sumber : data primer yang diolah

3. Usia

Jumlah responden berdasarkan usia, terdiri atas responden berusia 5-10 tahun sebanyak 14 atau 56\% responden berusia 10-11 tahun sebanyak 7 atau 36\% dan responden berusia 1112 tahun sebanyak 2 responden atau $8 \%$.

Usia responden

\begin{tabular}{|c|c|c|}
\hline Usia & Jumlah responden (orang) & Persentase (\%) \\
\hline$\leq 0-5$ & 0 & $0 \%$ \\
\hline $5-10$ & 14 & $56 \%$ \\
\hline $10-11$ & 9 & $36 \%$ \\
\hline $11-12$ & 2 & $8 \%$ \\
\hline
\end{tabular}

Sumber : data primer yang diolah 
Subyek penelitian ini berjumlah 25 siswa, 9 guru dan 4 karyawan. Penentuan subyek ini berdasarkan hasil rekomendasi dari dosen pembimbing. Dosen pembimbing merekomendasi siswa-siswi kelas V sekolah dasar sebagai obyek penelitian karena siswa-siswi dalam kelas ini menunjukkan karakteristik kurang mempunyai pemahaman pendidikan karakter.

Daftar nama siswa kelas V (Lima)

\begin{tabular}{|c|c|l|c|}
\hline No & No Induk & \multicolumn{1}{|c|}{ Nama Siswa } & L/P \\
\hline 1 & 2787 & Chintya Monicawati & $\mathrm{P}$ \\
\hline 2 & 2788 & Chairul Mafika & $\mathrm{P}$ \\
\hline 3 & 2825 & Eldo Dwi Nastata & $\mathrm{L}$ \\
\hline 4 & 2847 & Aden Firmansyah & $\mathrm{L}$ \\
\hline 5 & 2848 & Ahmad Rio Prasetyo & $\mathrm{L}$ \\
\hline 6 & 2849 & Arge Hendias Saputra & $\mathrm{P}$ \\
\hline 7 & 2850 & Ananda Satriyani & $\mathrm{P}$ \\
\hline 8 & 2852 & Anindya Cisna Pratista & $\mathrm{P}$ \\
\hline 9 & 2853 & Azizah Rizki Cahyani & $\mathrm{L}$ \\
\hline 10 & 2854 & Faizal Nur Lukman & $\mathrm{P}$ \\
\hline 11 & 2855 & Gabriela Santi Kuria A & $\mathrm{P}$ \\
\hline 12 & 2856 & Galuh Hammami & $\mathrm{L}$ \\
\hline 13 & 2857 & Leokendra Bayu Arzana P & $\mathrm{P}$ \\
\hline 14 & 2858 & Nana Nikmatus Z & $\mathrm{P}$ \\
\hline 15 & 2859 & Ninda Andarwati & $\mathrm{P}$ \\
\hline 16 & 2860 & Novita Sri Rahayu & $\mathrm{L}$ \\
\hline 17 & 2861 & Nur Rahmad Widiyanto & $\mathrm{L}$ \\
\hline 18 & 2862 & Rafi Ega Pradita & $\mathrm{L}$ \\
\hline 19 & 2863 & Rahmad Wahyudi & $\mathrm{L}$ \\
\hline 20 & 2864 & M.Angger Bimantara & $\mathrm{L}$ \\
\hline 21 & 2865 & Raka Pamungkas & $\mathrm{L}$ \\
\hline 22 & 2866 & Riski Afrian & $\mathrm{P}$ \\
\hline 23 & 2867 & Ratna Violeta Jasmin & $\mathrm{L}$ \\
\hline 24 & 2868 & Tico Herlambang Ardedat & $\mathrm{L}$ \\
\hline 25 & 2949 & Anjas Tri Nugroho & \\
\hline
\end{tabular}

Sumber : data dinding kelas

\section{Deskripsi Variabel}

\section{Pengelolaan sekolah dalam pembentukan karakter guru}

1. Aspek Pembelajaran Karakter

Guru wajib mengajar sesuai dengan jadwal pelajaran diukur berdasarkan pernyataan responden. 
Guru wajib mengajar sesuai dengan jadwal pelajaran

\begin{tabular}{|c|l|c|c|}
\hline Skor & \multicolumn{1}{|c|}{ Kategori } & Frekuensi (orang) & Persentase (\%) \\
\hline 4 & Sangat setuju & 5 & $38,5 \%$ \\
\hline 3 & Setuju & 8 & $61,5 \%$ \\
\hline 2 & Tidak setuju & 0 & $0 \%$ \\
\hline 1 & Sangat tidak setuju & 0 & $0 \%$ \\
\hline & Total & 13 & $100 \%$ \\
\hline
\end{tabular}

Sumber : data primer yang diolah

Berdasarkan dapat diketahui bahwa 8 orang guru atau $(61,5 \%)$ setuju wajib mengajar sesuai dengan jadwal pelajaran, sedangkan sebanyak 5 guru atau $(38,5 \%)$ sangat setuju mengajar sesuai dengan jadwal pelajaran.

2. Aspek Keteladanan guru dan karyawan

Guru wajib memberikan contoh sikap yang baik kepada siswa

\begin{tabular}{|c|l|c|c|}
\hline Skor & \multicolumn{1}{|c|}{ Kategori } & Frekuensi (orang) & Persentase (\%) \\
\hline 4 & Sangat setuju & 11 & $84,7 \%$ \\
\hline 3 & Setuju & 2 & $15,3 \%$ \\
\hline 2 & Tidak setuju & 0 & $0 \%$ \\
\hline 1 & Sangat tidak setuju & 0 & $0 \%$ \\
\hline & Total & 13 & $100 \%$ \\
\hline
\end{tabular}

Sumber : data primer yang diolah

Diketahui bahwa 11 atau $(84,7 \%)$ guru setuju untuk memberikan contoh sikap yang baik kepada siswa, sedangkan 2 atau (15,3\%) sangat setuju apabila guru memberikan contoh sikap yang baik kepada siswa.

Guru wajib mendidik siswa dengan ahklak terpuji, seperti berkata jujur, berbahasa yang baik

\begin{tabular}{|c|l|c|c|}
\hline Skor & \multicolumn{1}{|c|}{ Kategori } & Frekuensi (orang) & Persentase (\%) \\
\hline 4 & Sangat setuju & 6 & $46,2 \%$ \\
\hline 3 & Setuju & 7 & $53,8 \%$ \\
\hline 2 & Tidak setuju & 0 & $0 \%$ \\
\hline 1 & Sangat tidak setuju & 0 & $0 \%$ \\
\hline & Total & $\mathbf{1 3}$ & $100 \%$ \\
\hline
\end{tabular}

Sumber : data primer yang diolah

Diketahui bahwa 7 atau $(53,8 \%)$ guru setuju untuk mendidik siswa dengan ahklak terpuji, seperti berkata jujur, berbahasa yang baik, sedangkan sebanyak 6 atau (46,2\%) guru mengatakan sangat setuju untuk mendidik siswa dengan ahklak terpuji, seperti berkata jujur, berbahasa yang baik. 
3. Aspek Pembiasaan karakter

Guru mewajibkan siswa-siswi untuk berdoa sebelum pelajaran dimulai

\begin{tabular}{|c|l|c|c|}
\hline Skor & \multicolumn{1}{|c|}{ Kategori } & Frekuensi (orang) & Persentase (\%) \\
\hline 4 & Sangat setuju & 10 & $76,9 \%$ \\
\hline 3 & Setuju & 3 & $23,1 \%$ \\
\hline 2 & Tidak setuju & 0 & $0 \%$ \\
\hline 1 & Sangat tidak setuju & 0 & $0 \%$ \\
\hline & Total & $\mathbf{1 3}$ & $100 \%$ \\
\hline
\end{tabular}

Sumber : data primer yang diolah

Diketahui bahwa 10 atau $(76,9 \%)$ guru sangat setuju membiasakan siswa-siswi untuk berdoa sebelum pelajaran dimulai, sedangkan 3 atau $(23,1 \%)$ guru setuju membiasakan siswa-siswi untuk berdoa sebelum pelajaran dimulai.

Guru mewajibkan siswa-siswi untuk sholat dzuhur berjamaah di mushola

\begin{tabular}{|c|l|c|c|}
\hline Skor & \multicolumn{1}{|c|}{ Kategori } & Frekuensi (orang) & Persentase (\%) \\
\hline 4 & Sangat setuju & 11 & $84,7 \%$ \\
\hline 3 & Setuju & 2 & $15,3 \%$ \\
\hline 2 & Tidak setuju & 0 & $0 \%$ \\
\hline 1 & Sangat tidak setuju & 0 & $0 \%$ \\
\hline & Total & $\mathbf{1 3}$ & $100 \%$ \\
\hline
\end{tabular}

Sumber : data primer yang diolah

Diketahui bahwa 11 atau $(84,7 \%)$ guru sangat setuju untuk membiasakan siswa-siswi sholat dzuhur berjamaah di mushola, sedangkan 2 atau $(15,3 \%)$ guru setuju untuk membiasakan siswasiswi sholat dzuhur berjamaah di mushola.

4. Aspek Pemotivasian Siswa

Guru harus menciptakan suasana yang kondusif di dalam kelas

\begin{tabular}{|c|l|c|c|}
\hline Skor & \multicolumn{1}{|c|}{ Kategori } & Frekuensi (orang) & Persentase (\%) \\
\hline 4 & Sangat setuju & 9 & $69,2 \%$ \\
\hline 3 & Setuju & 4 & $30,8 \%$ \\
\hline 2 & Tidak setuju & 0 & $0 \%$ \\
\hline 1 & Sangat tidak setuju & 0 & $0 \%$ \\
\hline & Total & $\mathbf{1 3}$ & $100 \%$ \\
\hline
\end{tabular}

Sumber : data primer yang diolah 
Diketahui bahwa sebagian besar 4 orang setuju guru harus menciptakan suasana yang kondusif di dalam kelas, sedangkan sebanyak 9 orang sangat setuju apabila guru harus selalu menciptakan suasana kondusif di dalam kelas.

Guru memberikan nasehat kepada siswa-siswi yang sering terlambat masuk sekolah

\begin{tabular}{|c|l|c|c|}
\hline Skor & \multicolumn{1}{|c|}{ Kategori } & Frekuensi (orang) & Persentase (\%) \\
\hline 4 & Sangat setuju & 8 & $61,5 \%$ \\
\hline 3 & Setuju & 5 & $38,5 \%$ \\
\hline 2 & Tidak setuju & 0 & $0 \%$ \\
\hline 1 & Sangat tidak setuju & 0 & $0 \%$ \\
\hline & Total & $\mathbf{1 3}$ & $100 \%$ \\
\hline
\end{tabular}

Sumber : data primer yang diolah.

Diketahui bahwa sebagian besar 11 atau (84,7\%) guru sangat setuju untuk memberi hukuman kepada siswa yang melanggar aturan sekolah, sedangkan 2 atau $(15,3 \%)$ guru setuju untuk memberikan hukuman kepada siswa yang melanggar aturan sekolah.

Gambaran dari masing-masing deskripsi variabel ini adalah indikator dari 18 nilai-nilai pendidikan karakter adalah sebagai berikut :

\section{Nilai Religius}

Nilai indikator Religius

Siswa diwajibkan untuk berdoa sebelum dan sesudah pelajaran dimulai

\begin{tabular}{|c|l|c|c|}
\hline Skor & \multicolumn{1}{|c|}{ Kategori } & Frekuensi (orang) & Persentase (\%) \\
\hline 4 & Sangat setuju & 9 & $36 \%$ \\
\hline 3 & Setuju & 16 & $64 \%$ \\
\hline 2 & Tidak setuju & 0 & $0 \%$ \\
\hline 1 & Sangat tidak setuju & 0 & $0 \%$ \\
\hline & Total & $\mathbf{2 5}$ & $100 \%$ \\
\hline
\end{tabular}

Sumber : data primer yang diolah

Diketahui bahwa sebagian besar 16 atau (64\%) setuju siswa diwajibkan untuk berdoa sebelum dan sesudah pelajaran dimulai, sedangkan 9 atau (36\%) guru sangat setuju siswa diwajibkan untuk berdoa sebelum dan sesudah pelajaran dimulai.

Siswa-siswi diwajibkan sholat dzuhur berjamaah di mushola

\begin{tabular}{|c|l|c|c|}
\hline Skor & \multicolumn{1}{|c|}{ Kategori } & Frekuensi (orang) & Persentase (\%) \\
\hline 4 & Sangat setuju & 12 & $48 \%$ \\
\hline 3 & Setuju & 12 & $48 \%$ \\
\hline 2 & Tidak setuju & 0 & $0 \%$ \\
\hline 1 & Sangat tidak setuju & 1 & $4 \%$ \\
\hline & Total & $\mathbf{2 5}$ & $100 \%$ \\
\hline
\end{tabular}

Sumber : data primer yang diolah 
Diketahui bahwa 12 atau (48\%) sangat setuju siswa-siswi sholat dzuhur berjamaah di mushola, sedangkan 12 atau (24\%) setuju siswa-siswi sholat dzuhur berjamaah di mushola dan 1 atau (4\%) siswa menjawab tidak setuju karena siswa tersebut beragama Katholik.

Siswa wajib memperingati hari besar keagamaan menurut agama dan keyakinannya.

\begin{tabular}{|c|l|c|c|}
\hline Skor & \multicolumn{1}{|c|}{ Kategori } & Frekuensi (orang) & Persentase (\%) \\
\hline 4 & Sangat setuju & 9 & $36 \%$ \\
\hline 3 & Setuju & 16 & $64 \%$ \\
\hline 2 & Tidak setuju & 0 & $\%$ \\
\hline 1 & Sangat tidak setuju & 0 & $0 \%$ \\
\hline & Total & $\mathbf{2 5}$ & $100 \%$ \\
\hline
\end{tabular}

Sumber : data primer yang diolah

Diketahui bahwa sebagian besar 16 atau (64\%) siswa setuju wajib memperingati hari besar keagamaan menurut agama dan keyakinanya, sedangkan sebanyak 7 orang atau (28\%) menjawab sangat baik dan 2 orang atau $8 \%$ menjawab cukup baik.

Siswa diwajibkan memberi salam kepada Bapak/ Ibu guru

\begin{tabular}{|c|l|c|c|}
\hline Skor & \multicolumn{1}{|c|}{ Kategori } & Frekuensi (orang) & Persentase (\%) \\
\hline 4 & Sangat setuju & 11 & $44 \%$ \\
\hline 3 & Setuju & 14 & $56 \%$ \\
\hline 2 & Tidak setuju & 0 & $0 \%$ \\
\hline 1 & Sangat tidak setuju & 0 & $0 \%$ \\
\hline & Total & $\mathbf{2 5}$ & $100 \%$ \\
\hline
\end{tabular}

Sumber : data primer yang diolah

Diketahui bahwa sebagian besar 14 atau (56\%) siswa setuju diwajibkan memberi salam kepada Bapak/ Ibu guru, sedangkan 11 atau (44\%) siswa sangat setuju untuk diwajibkan memberi salam kepada Bapak/ Ibu guru.

\section{Nilai Jujur}

Nilai indikator Jujur

Siswa dilarang mencontek pekerjaan teman

\begin{tabular}{|c|l|c|c|}
\hline Skor & \multicolumn{1}{|c|}{ Kategori } & Frekuensi (orang) & Persentase (\%) \\
\hline 4 & Sangat setuju & 14 & $56 \%$ \\
\hline 3 & Setuju & 11 & $44 \%$ \\
\hline 2 & Tidak setuju & 0 & $0 \%$ \\
\hline 1 & Sangat tidak setuju & 0 & $0 \%$ \\
\hline & Total & $\mathbf{2 5}$ & $100 \%$ \\
\hline
\end{tabular}

Sumber : data primer yang diolah 
Diketahui bahwa 11 atau (44\%) siswa setuju untuk tidak mencontek pekerjaan teman, sedangkan 14 atau (56\%) siswa sangat setuju untuk tidak mencontek pekerjaan teman.

Siswa harus mengerjakan tugas secara teliti dan benar.

\begin{tabular}{|c|l|c|c|}
\hline Skor & \multicolumn{1}{|c|}{ Kategori } & Frekuensi (orang) & Persentase (\%) \\
\hline 4 & Sangat setuju & 10 & $40 \%$ \\
\hline 3 & Setuju & 15 & $60 \%$ \\
\hline 2 & Tidak setuju & 0 & $0 \%$ \\
\hline 1 & Sangat tidak setuju & 0 & $0 \%$ \\
\hline & Total & $\mathbf{2 5}$ & $100 \%$ \\
\hline
\end{tabular}

Sumber : data primer yang diolah

Diketahui bahwa 15 atau (60\%) siswa setuju harus mengerjakan tugas secara teliti dan benar, sedangkan 10 atau (40\%) siswa sangat setuju harus mengerjakan tugas secara teliti dan benar.

Siswa dilarang berbohong pada orang tua/ guru

\begin{tabular}{|c|l|c|c|}
\hline Skor & \multicolumn{1}{|c|}{ Kategori } & Frekuensi (orang) & Persentase (\%) \\
\hline 4 & Sangat setuju & 13 & $52 \%$ \\
\hline 3 & setuju & 12 & $48 \%$ \\
\hline 2 & Tidak setuju & 0 & $0 \%$ \\
\hline 1 & Sangat tidak setuju & 0 & $0 \%$ \\
\hline & Total & $\mathbf{2 5}$ & $100 \%$ \\
\hline
\end{tabular}

Sumber : data primer yang diolah

Diketahui bahwa 13 atau (52\%) siswa sangat setuju untuk dilarang berbohong kepada orang tua/ guru, sedangkan 12 atau (48\%) siswa menjawab sangat setuju dilarang berbohong pada orang tua/ guru.

Siswa disarankan untuk membaca buku diperpustakaan sekolah pada jam istirahat/ jam kosong

\begin{tabular}{|c|l|c|c|}
\hline Skor & \multicolumn{1}{|c|}{ Kategori } & Frekuensi (orang) & Persentase (\%) \\
\hline 4 & Sangat setuju & 9 & $36 \%$ \\
\hline 3 & Setuju & 16 & $64 \%$ \\
\hline 2 & Tidak setuju & 0 & $0 \%$ \\
\hline 1 & Sangat tidak setuju & 0 & $0 \%$ \\
\hline & Total & $\mathbf{2 5}$ & $100 \%$ \\
\hline
\end{tabular}

Sumber : data primer yang diolah

Diketahui bahwa 16 atau (64\%) menjawab setuju siswa disarankan untuk membaca buku di perpustakaan sekolah pada jam istirahat/ kosong, sedangkan 9 atau (8\%) siswa menjawab sangat setuju siswa disarankan untuk membaca buku di perpusakaan pada jam istirahat/ jam kosong. 


\section{Nilai Toleransi}

Nilai indikator Toleransi

Siswa harus menghormati teman yang berbeda adat istiadat

\begin{tabular}{|c|l|c|c|}
\hline Skor & \multicolumn{1}{|c|}{ Kategori } & Frekuensi (orang) & Persentase (\%) \\
\hline 4 & Sangat setuju & 12 & $48 \%$ \\
\hline 3 & Setuju & 13 & $52 \%$ \\
\hline 2 & Tidak setuju & 0 & $0 \%$ \\
\hline 1 & Sangat tidak setuju & 0 & $0 \%$ \\
\hline & Total & $\mathbf{2 5}$ & $100 \%$ \\
\hline
\end{tabular}

Sumber : data primer yang diolah

Diketahui bahwa 13 atau (52\%) siswa setuju untuk menghormati teman yang berbeda adat istiadat, sedangkan sebanyak 12 atau (52\%) siswa menjawab sangat setuju untuk menghormati teman yang berbeda adat istiadat.

Siswa sebaiknya mudah bergaul dengan kelas lain

\begin{tabular}{|c|l|c|c|}
\hline Skor & \multicolumn{1}{|c|}{ Kategori } & Frekuensi (orang) & Persentase (\%) \\
\hline 4 & Sangat setuju & 12 & $48 \%$ \\
\hline 3 & Setuju & 12 & $48 \%$ \\
\hline 2 & Tidak setuju & 1 & $4 \%$ \\
\hline 1 & Sangat tidak setuju & 0 & $0 \%$ \\
\hline & Total & $\mathbf{2 5}$ & $100 \%$ \\
\hline
\end{tabular}

Sumber : data primer yang diolah

Diketahui bahwa sebagian besar siswa setuju untuk mudah bergaul dengan kelas lain, sedang 1 atau (4\%) menjawab kurang setuju untuk mudah bergaul dengan kelas lain.

Siswa harus selalu menghargai kemampuan orang lain

\begin{tabular}{|c|l|c|c|}
\hline Skor & \multicolumn{1}{|c|}{ Kategori } & Frekuensi (orang) & Persentase (\%) \\
\hline 4 & Sangat setuju & 7 & $28 \%$ \\
\hline 3 & Setuju & 16 & $64 \%$ \\
\hline 2 & Tidak setuju & 2 & $8 \%$ \\
\hline 1 & Sangat tidak setuju & 0 & $0 \%$ \\
\hline & Total & $\mathbf{2 5}$ & $100 \%$ \\
\hline
\end{tabular}

Sumber : data primer yang diolah

Diketahui bahwa 16 atau (64\%) siswa setuju untuk selalu menghargai kemampuan orang lain, sedangkan 7 atau (28\%) menjawab sangat setuju, dan 2 atau (8\%) menjawab tidak setuju.

Siswa harus menghargai pendapat teman 


\begin{tabular}{|c|l|c|c|}
\hline Skor & \multicolumn{1}{|c|}{ Kategori } & Frekuensi (orang) & Persentase (\%) \\
\hline 4 & Sangat setuju & 11 & $44 \%$ \\
\hline 3 & Setuju & 14 & $56 \%$ \\
\hline 2 & Tidak setuju & 0 & $0 \%$ \\
\hline 1 & Sangat tidak setuju & 0 & $0 \%$ \\
\hline & Total & $\mathbf{2 5}$ & $100 \%$ \\
\hline
\end{tabular}

Sumber : data primer yang diolah

Diketahui bahwa sebagian besar 14 atau (48\%) siswa menjawab setuju untuk menghargai pendapat teman, sedangkan 11 atau (44\%) siswa menjawab sangat setuju untuk menghargai pendapat teman.

\section{Nilai Disiplin}

Nilai indikator Disiplin

Siswa wajib menjaga kebersihan kelas maupun diluar kelas

\begin{tabular}{|c|l|c|c|}
\hline Skor & \multicolumn{1}{|c|}{ Kategori } & Frekuensi (orang) & Persentase (\%) \\
\hline 4 & Sangat setuju & 11 & $44 \%$ \\
\hline 3 & Setuju & 14 & $56 \%$ \\
\hline 2 & Tidak setuju & 0 & $0 \%$ \\
\hline 1 & Sangat tidak setuju & 0 & $0 \%$ \\
\hline & Total & $\mathbf{2 5}$ & $100 \%$ \\
\hline
\end{tabular}

Sumber : data primer yang diolah

Diketahui bahwa 14 atau (56\%) setuju untuk selalu menjaga kebersihan kelas muaupun diluar kelas, sedangkan 11 atau (44\%) siswa menjawab sangat setuju untuk selalu menjaga kebersihan kelas maupun luar kelas.

Siswa diharuskan untuk berbicara sopan kepada guru/orang tua

\begin{tabular}{|c|l|c|c|}
\hline Skor & \multicolumn{1}{|c|}{ Kategori } & Frekuensi (orang) & Persentase (\%) \\
\hline 4 & Sangat setuju & 7 & $28 \%$ \\
\hline 3 & Setuju & 18 & $72 \%$ \\
\hline 2 & Tidak setuju & 0 & $0 \%$ \\
\hline 1 & Sangat tidak setuju & 0 & $0 \%$ \\
\hline & Total & $\mathbf{2 5}$ & $100 \%$ \\
\hline
\end{tabular}

Sumber : data primer yang diolah

Diketahui bahwa 18 atau (72\%) siswa menjawab setuju untuk berbicara sopan kepada guru/ orang tua, sedangkan 7 atau (68\%) siswa menjawab sangat setuju untuk berbicara sopan kepada guru/ orang tua. 
Siswa harus selalu mematuhi tata tertib di sekolah

\begin{tabular}{|c|l|c|c|}
\hline Skor & \multicolumn{1}{|c|}{ Kategori } & Frekuensi (orang) & Persentase (\%) \\
\hline 4 & Sangat setuju & 8 & $32 \%$ \\
\hline 3 & Setuju & 17 & $68 \%$ \\
\hline 2 & Tidak setuju & 0 & $0 \%$ \\
\hline 1 & Sangat tidak setuju & 0 & $0 \%$ \\
\hline & Total & $\mathbf{2 5}$ & $100 \%$ \\
\hline
\end{tabular}

Sumber : data primer yang diolah

Diketahui bahwa sebagian besar 17 atau (68\%) siswa setuju siswa harus selalu mematuhi tata tertib disekolah, sedangkan 8 atau (32\%) siswa menjawab sangat setuju.

Siswa diharap hadir 15 menit sebelum pelajaran dimulai

\begin{tabular}{|c|l|c|c|}
\hline Skor & \multicolumn{1}{|c|}{ Kategori } & Frekuensi (orang) & Persentase (\%) \\
\hline 1 & Sangat setuju & 10 & $40 \%$ \\
\hline 2 & Setuju & 12 & $48 \%$ \\
\hline 3 & Tidak setuju & 3 & $12 \%$ \\
\hline 4 & Sangat tidak setuju & 0 & $0 \%$ \\
\hline & Total & $\mathbf{2 5}$ & $100 \%$ \\
\hline
\end{tabular}

Sumber : data primer yang diolah

Diketahui bahwa sebagian besar 12 atau (48\%) siswa setuju apabila siswa di harap hadir 15 menit sebelum pelajaran dimulai, sedangkan 10 atau (40\%) menjawab sangat setuju, 3 orang atau (12\%) dan 3 orang atau (12\%) menyebut tidak setuju.

Siswa diharap untuk memakai seragam sekolah

\begin{tabular}{|c|l|c|c|}
\hline Skor & \multicolumn{1}{|c|}{ Kategori } & Frekuensi (orang) & Persentase (\%) \\
\hline 4 & Sangat setuju & 14 & $56 \%$ \\
\hline 3 & Setuju & 11 & $44 \%$ \\
\hline 2 & Tidak setuju & 0 & $0 \%$ \\
\hline 1 & Sangat tidak setuju & 0 & $0 \%$ \\
\hline & Total & $\mathbf{2 5}$ & $100 \%$ \\
\hline
\end{tabular}

Sumber : data primer yang diolah

Diketahui bahwa sebagian besar 14 atau (44\%) siswa menjawab sangat setuju untuk memakai seragam sekolah, sedangkan 11 atau (56\%) siswa menjawab setuju untuk memakai seragam sekolah. 


\section{Nilai Kerja keras}

Nilai indikator Kerja keras

Untuk berprestasi di sekolah, siswa harus rajin belajar

\begin{tabular}{|c|l|c|c|}
\hline Skor & \multicolumn{1}{|c|}{ Kategori } & Frekuensi (orang) & Persentase (\%) \\
\hline 4 & Sangat setuju & 13 & $52 \%$ \\
\hline 3 & Setuju & 12 & $48 \%$ \\
\hline 2 & Tidak setuju & 0 & $0 \%$ \\
\hline 1 & Sangat tidak setuju & 0 & $0 \%$ \\
\hline & Total & $\mathbf{2 5}$ & $100 \%$ \\
\hline
\end{tabular}

Sumber : data primer yang diolah

Diketahui bahwa sebagian besar 13 atau (52\%) siswa setuju untuk berprestasi di sekolah, siswa harus rajin belajar, sedangkan 12 atau (48\%) siswa menjawab setuju.

Siswa berani berkompetisi secara jujur dan adil dengan sekolah lain.

\begin{tabular}{|c|l|c|c|}
\hline Skor & \multicolumn{1}{|c|}{ Kategori } & Frekuensi (orang) & Persentase (\%) \\
\hline 4 & Sangat setuju & 10 & $40 \%$ \\
\hline 3 & Setuju & 15 & $60 \%$ \\
\hline 2 & Tidak setuju & 0 & $0 \%$ \\
\hline 1 & Sangat tidak setuju & 0 & $0 \%$ \\
\hline & Total & $\mathbf{2 5}$ & $100 \%$ \\
\hline
\end{tabular}

Sumber : data primer yang diolah

Diketahui bahwa sebagian besar 15 atau (60\%) siswa setuju berani berkompetisi secara jujur dan adil dengan sekolah lain, sedangkan 10 atau (40\%) siswa sangat setuju untuk berkompetisi secara jujur dan adil dengan sekolah lain.

Siswa diwajibkan harus selalu fokus pada pelajaran di kelas

\begin{tabular}{|c|l|c|c|}
\hline Skor & \multicolumn{1}{|c|}{ Kategori } & Frekuensi (orang) & Persentase (\%) \\
\hline 4 & Sangat setuju & 7 & $28 \%$ \\
\hline 3 & Setuju & 18 & $72 \%$ \\
\hline 2 & Tidak setuju & 1 & $4 \%$ \\
\hline 1 & Sangat tidak setuju & 0 & $0 \%$ \\
\hline & Total & $\mathbf{2 5}$ & $100 \%$ \\
\hline
\end{tabular}

Sumber : data primer yang diolah

Diketahui bahwa sebagian besar 18 atau (72\%) siswa setuju untuk fokus pada mata pelajaran dikelas, sedangkan 7 atau (28\%) siswa sangat setuju untuk fokus pada mata pelajaran di kelas dan 1 atau (4\%) siswa menjawab tidak setuju.

Siswa diharap jangan cepat putus asa dalam menghadapi kesulitan dalam belajar. 


\begin{tabular}{|c|l|c|c|}
\hline Skor & \multicolumn{1}{|c|}{ Kategori } & Frekuensi (orang) & Persentase (\%) \\
\hline 4 & Sangat setuju & 13 & $52 \%$ \\
\hline 3 & Setuju & 12 & $48 \%$ \\
\hline 2 & Tidak setuju & 0 & $0 \%$ \\
\hline 1 & Sangat tidak setuju & 0 & $0 \%$ \\
\hline & Total & $\mathbf{2 5}$ & $100 \%$ \\
\hline
\end{tabular}

Sumber : data primer yang diolah

Diketahui bahwa sebagian besar 13 atau (44\%) siswa sangat setuju untuk tidak cepat putus asa dalam menghadapi kesulitan dalam belajar, sedangkan 12 atau (52\%) siswa setuju untuk tidak cepat putus asa dalam menghadapi kesulitan dalam belajar.

\section{Nilai Kreatif}

Nilai indikator Kreatif

Siswa harus berani mengemukakan pendapat kepada guru

\begin{tabular}{|c|l|c|c|}
\hline Skor & \multicolumn{1}{|c|}{ Kategori } & Frekuensi (orang) & Persentase (\%) \\
\hline 4 & Sangat setuju & 9 & $36 \%$ \\
\hline 3 & Setuju & 16 & $64 \%$ \\
\hline 2 & Tidak setuju & 0 & $0 \%$ \\
\hline 1 & Sangat tidak setuju & 0 & $0 \%$ \\
\hline & Total & $\mathbf{2 5}$ & $100 \%$ \\
\hline
\end{tabular}

Sumber : data primer yang diolah

Diketahui bahwa sebagian besar 16 atau (64\%) siswa setuju harus berani mengemukakan pendapat kepada guru, sedangkan 9 atau (36\%) siswa sangat setuju harus berani mengemukakan pendapat kepada guru.

Siswa diharapkan mampu untuk menciptakan ide-ide baru di sekolah

\begin{tabular}{|c|l|c|c|}
\hline Skor & \multicolumn{1}{|c|}{ Kategori } & Frekuensi (orang) & Persentase (\%) \\
\hline 4 & Sangat setuju & 11 & $44 \%$ \\
\hline 3 & Setuju & 14 & $56 \%$ \\
\hline 2 & Tidak setuju & 0 & $0 \%$ \\
\hline 1 & Sangat tidak setuju & 0 & $0 \%$ \\
\hline & Total & $\mathbf{2 5}$ & $100 \%$ \\
\hline
\end{tabular}

Sumber : data primer yang diolah

Diketahui bahwa sebagian besar 14 atau (56\%) siswa setuju mampu menciptakan ide-ide baru di sekolah, sedangkan 11 atau (44\%) siswa sangat setuju mampu menciptakan ide-ide baru di sekolah. 
Siswa diwajibkan untuk melakukan hai-hal yang positif

\begin{tabular}{|c|l|c|c|}
\hline Skor & \multicolumn{1}{|c|}{ Kategori } & Frekuensi (orang) & Persentase (\%) \\
\hline 4 & Sangat setuju & 8 & $32 \%$ \\
\hline 3 & Setuju & 17 & $68 \%$ \\
\hline 2 & Tidak setuju & 0 & $0 \%$ \\
\hline 1 & Sangat tidak setuju & 0 & $0 \%$ \\
\hline & Total & $\mathbf{2 5}$ & $100 \%$ \\
\hline
\end{tabular}

Sumber : data primer yang diolah

Diketahui bahwa sebagian besar 17 atau (68\%) siswa setuju untuk melakukan hal-hal yang positif, sedangkan 8 atau (32\%) siswa sangat setuju untuk melakukan hal-hal yang positif.

Siswa harus berani melakukan sesuatu untuk mengasilkan cara/ hasil baru dari apa yang telah dimiliki

\begin{tabular}{|c|l|c|c|}
\hline Skor & \multicolumn{1}{|c|}{ Kategori } & Frekuensi (orang) & Persentase (\%) \\
\hline 4 & Sangat setuju & 10 & $40 \%$ \\
\hline 3 & Setuju & 15 & $60 \%$ \\
\hline 2 & Tidak setuju & 0 & $0 \%$ \\
\hline 1 & Sangat tidak setuju & 0 & $0 \%$ \\
\hline & Total & $\mathbf{2 5}$ & $100 \%$ \\
\hline
\end{tabular}

Sumber : data primer yang diolah

Diketahui bahwa sebagian besar 15 atau (60\%) siswa setuju harus berani melakukan sesuatu untuk menghasilkan cara/ hasil baru dari apa yang telah dimiliki, sedangkan 10 atau (40\%) siswa sangat setuju harus berani melakukan sesuatu menghasilkan cara/ hasil yang dimiliki.

\section{Nilai Mandiri}

Nilai indikator Mandiri

Siswa diwajibkan mengerjakan soal ulangan tanpa bantuan orang lain

\begin{tabular}{|c|l|c|c|}
\hline Skor & \multicolumn{1}{|c|}{ Kategori } & Frekuensi (orang) & Persentase (\%) \\
\hline 4 & Sangat setuju & 11 & $44 \%$ \\
\hline 3 & Setuju & 14 & $56 \%$ \\
\hline 2 & Tidak setuju & 0 & $0 \%$ \\
\hline 1 & Sangat tidak setuju & 0 & $0 \%$ \\
\hline & Total & $\mathbf{2 5}$ & $100 \%$ \\
\hline
\end{tabular}

Sumber : data primer yang diolah

Diketahui bahwa sebagian besar 14 atau (56\%) siswa setuju untuk mengerjakan soal ulangan tanpa bantuan orang lain, sedangkan

11 atau (44\%) siswa sangat setuju untuk mengerjakan soal ulangan tanpa bantuan orang lain 
Siswa diwajibkan untuk selalu mengerjakan PR di rumah

\begin{tabular}{|c|l|c|c|}
\hline Skor & \multicolumn{1}{|c|}{ Kategori } & Frekuensi (orang) & Persentase (\%) \\
\hline 4 & Sangat setuju & 9 & $36 \%$ \\
\hline 3 & Setuju & 16 & $64 \%$ \\
\hline 2 & Tidak setuju & 0 & $0 \%$ \\
\hline 1 & Sangat tidak setuju & 0 & $0 \%$ \\
\hline & Total & $\mathbf{2 5}$ & $100 \%$ \\
\hline
\end{tabular}

Sumber : data primer yang diolah

Diketahui bahwa sebagian besar 16 atau (64\%) siswa setuju siswa diwajibkan untuk selalu mengerjakan PR di rumah, sedangkan 9 atau (36\%) siswa sangat setuju siswa diwajibkan untuk selalu mengerjakan PR di rumah.

Siswa wajib mengerjakan tugas yang bersifat individu

\begin{tabular}{|c|l|c|c|}
\hline Skor & \multicolumn{1}{|c|}{ Kategori } & Frekuensi (orang) & Persentase (\%) \\
\hline 4 & Sangat setuju & 8 & $32 \%$ \\
\hline 3 & Setuju & 17 & $68 \%$ \\
\hline 2 & Tidak setuju & 0 & $0 \%$ \\
\hline 1 & Sangat tidak setuju & 0 & $0 \%$ \\
\hline & Total & $\mathbf{2 5}$ & $100 \%$ \\
\hline
\end{tabular}

Sumber : data primer yang diolah

Diketahui bahwa sebagian besar 17 atau (48\%) siswa setuju siswa wajib mengerjakan tugas yang bersifat individu, sedangkan 5 atau (20\%) siswa sangat setuju siswa wajib mengerjakan tugas yang bersifat individu.

Siswa mengerjakan sendiri tugas yang menjadi tanggung jawabnya

\begin{tabular}{|c|l|c|c|}
\hline Skor & \multicolumn{1}{|c|}{ Kategori } & Frekuensi (orang) & Persentase (\%) \\
\hline 4 & Sangat setuju & 10 & $40 \%$ \\
\hline 3 & Setuju & 15 & $60 \%$ \\
\hline 2 & Tidak setuju & 0 & $0 \%$ \\
\hline 1 & Sangat tidak setuju & 0 & $0 \%$ \\
\hline & Total & $\mathbf{2 5}$ & $100 \%$ \\
\hline
\end{tabular}

Sumber : data primer yang diolah

Diketahui bahwa sebagian besar 15 atau (60\%) siswa setuju untuk mengerjakan sendiri tugas yang menjadi tanggung jawabnya, sedangkan 10 atau (40\%) siswa sangat setuju untuk mengerjakan sendiri tugas yang menjadi tanggung jawabnya. 


\section{Nilai Demokratis}

Siswa tidak diperbolehkan memaksa kehendak kepada orang lain

\begin{tabular}{|c|l|c|c|}
\hline Skor & \multicolumn{1}{|c|}{ Kategori } & Frekuensi (orang) & Persentase (\%) \\
\hline 4 & Sangat setuju & 12 & $48 \%$ \\
\hline 3 & Setuju & 13 & $52 \%$ \\
\hline 2 & Tidak setuju & 0 & $0 \%$ \\
\hline 1 & Sangat tidak setuju & 0 & $0 \%$ \\
\hline & Total & $\mathbf{2 5}$ & $100 \%$ \\
\hline
\end{tabular}

Sumber : data primer yang diolah

Diketahui bahwa sebagian besar 13 atau (52\%) siswa setuju untuk tidak memaksa kehendak kepada orang lain, sedangkan 12 atau (48\%) siswa sangat setuju untuk tidak memaksa kehendak orang lain.

\section{Nilai Rasa ingin tau}

Siswa harus membiasakan membaca media cetak di sekolahan, misal: membaca koran, membaca majalah, komik.

\begin{tabular}{|c|l|c|c|}
\hline Skor & \multicolumn{1}{|c|}{ Kategori } & Frekuensi (orang) & Persentase (\%) \\
\hline 4 & Sangat setuju & 14 & $56 \%$ \\
\hline 3 & Setuju & 11 & $44 \%$ \\
\hline 2 & Tidak setuju & 0 & $0 \%$ \\
\hline 1 & Sangat tidak setuju & 0 & $0 \%$ \\
\hline & Total & $\mathbf{2 5}$ & $100 \%$ \\
\hline
\end{tabular}

Sumber : data primer yang diolah

Diketahui bahwa sebagian besar 14 atau (32\%) siswa setuju untuk membiasakan membaca media cetak di sekolah, misal koran, majalah, komik, sedangkan 11 atau (36\%) siswa sangat setuju untuk membiasakan membaca media cetak di sekolah.

Pembelajaran di sekolah diarahkan untuk mengekplorasi keingintahuan siswa

\begin{tabular}{|c|l|c|c|}
\hline Skor & \multicolumn{1}{|c|}{ Kategori } & Frekuensi (orang) & Persentase (\%) \\
\hline 4 & Sangat setuju & 12 & $48 \%$ \\
\hline 3 & Setuju & 13 & $52 \%$ \\
\hline 2 & Tidak setuju & 0 & $0 \%$ \\
\hline 1 & Sangat tidak setuju & 0 & $0 \%$ \\
\hline & Total & $\mathbf{2 5}$ & $100 \%$ \\
\hline
\end{tabular}

Sumber : data primer yang diolah 


\section{Nilai Semangat kebangsaan}

Nilai indikator Semangat kebangsaan

Siswa diwajibkan untuk mengenali para pahlawan bangsa

\begin{tabular}{|c|l|c|c|}
\hline Skor & \multicolumn{1}{|c|}{ Kategori } & Frekuensi (orang) & Persentase (\%) \\
\hline 4 & Sangat setuju & 12 & $48 \%$ \\
\hline 3 & Setuju & 13 & $52 \%$ \\
\hline 2 & Tidak setuju & 0 & $0 \%$ \\
\hline 1 & Sangat tidak setuju & 0 & $0 \%$ \\
\hline & Total & $\mathbf{2 5}$ & $100 \%$ \\
\hline
\end{tabular}

Sumber : data primer yang diolah

Diketahui bahwa sebagian besar 13 atau (40\%) siswa setuju diwajibkan untuk mengenali para pahlawan bangsa, sedangkan 12 atau (48\%) siswa sangat setuju diwajibkan untuk mengenali para pahlawan bangsa

Siswa wajib mengikutsertakan dalam kegiatan kebangsaan

\begin{tabular}{|c|l|c|c|}
\hline Skor & \multicolumn{1}{|c|}{ Kategori } & Frekuensi (orang) & Persentase (\%) \\
\hline 4 & Sangat setuju & 12 & $48 \%$ \\
\hline 3 & Setuju & 13 & $52 \%$ \\
\hline 2 & Tidak setuju & 0 & $0 \%$ \\
\hline 1 & Sangat tidak setuju & 0 & $0 \%$ \\
\hline & Total & $\mathbf{2 5}$ & $100 \%$ \\
\hline
\end{tabular}

Sumber : data primer yang diolah

\section{Nilai Cinta tanah air}

Siswa harus ikut serta memajang bendera, pancasila, gambar presiden, serta simbol-simbol negara lain dikelas

\begin{tabular}{|c|l|c|c|}
\hline Skor & \multicolumn{1}{|c|}{ Kategori } & Frekuensi (orang) & Persentase (\%) \\
\hline 4 & Sangat setuju & 9 & $36 \%$ \\
\hline 3 & Setuju & 16 & $64 \%$ \\
\hline 2 & Tidak setuju & 0 & $0 \%$ \\
\hline 1 & Sangat tidak setuju & 0 & $0 \%$ \\
\hline & Total & $\mathbf{2 5}$ & $100 \%$ \\
\hline
\end{tabular}

Sumber : data primer yang diolah

Diketahui bahwa sebagian besar 16 atau (64\%) siswa setuju ikut serta memajang bendera, pancasila, gambar presiden, serta simbol-simbol negara lain di kelas.

Siswa diwajibkan untuk menggunakan bahasa dengan baik dan benar di sekolah maupun dirumah. 


\begin{tabular}{|c|l|c|c|}
\hline Skor & \multicolumn{1}{|c|}{ Kategori } & Frekuensi (orang) & Persentase (\%) \\
\hline 4 & Sangat setuju & 10 & $40 \%$ \\
\hline 3 & Setuju & 15 & $60 \%$ \\
\hline 2 & Tidak setuju & 0 & $0 \%$ \\
\hline 1 & Sangat tidak setuju & 0 & $0 \%$ \\
\hline & Total & $\mathbf{2 5}$ & $100 \%$ \\
\hline
\end{tabular}

Sumber : data primer yang diolah

\section{Nilai Menghargai prestasi}

Siswa diperbolehkan memajang hasil karya siswa di sekolah

\begin{tabular}{|c|l|c|c|}
\hline Skor & \multicolumn{1}{|c|}{ Kategori } & Frekuensi (orang) & Persentase (\%) \\
\hline 4 & Sangat setuju & 7 & $28 \%$ \\
\hline 3 & Setuju & 18 & $72 \%$ \\
\hline 2 & Tidak setuju & 0 & $0 \%$ \\
\hline 1 & Sangat tidak setuju & 0 & $0 \%$ \\
\hline & Total & $\mathbf{2 5}$ & $100 \%$ \\
\hline
\end{tabular}

Sumber : data primer yang diolah

Diketahui bahwa sebagian besar 18 atau (72\%) siswa setuju memajang hasil karya siswa di sekolah. Bagi siswa yang berprestasi akan diberikan reward dari sekolah.

\begin{tabular}{|c|l|c|c|}
\hline Skor & \multicolumn{1}{|c|}{ Kategori } & Frekuensi (orang) & Persentase (\%) \\
\hline 4 & Sangat setuju & 7 & $28 \%$ \\
\hline 3 & Setuju & 18 & $72 \%$ \\
\hline 2 & Tidak setuju & 0 & $0 \%$ \\
\hline 1 & Sangat tidak setuju & 0 & $0 \%$ \\
\hline & Total & $\mathbf{2 5}$ & $100 \%$ \\
\hline
\end{tabular}

Sumber : data primer yang diolah

13. Nilai Bersahabat/ komunikatif

Siswa harus saling menghargai dan menghormati sesama teman

\begin{tabular}{|c|l|c|c|}
\hline Skor & \multicolumn{1}{|c|}{ Kategori } & Frekuensi (orang) & Persentase (\%) \\
\hline 4 & Sangat setuju & 10 & $40 \%$ \\
\hline 3 & Setuju & 15 & $60 \%$ \\
\hline 2 & Tidak setuju & 0 & $0 \%$ \\
\hline 1 & Sangat tidak setuju & 0 & $0 \%$ \\
\hline & Total & $\mathbf{2 5}$ & $100 \%$ \\
\hline
\end{tabular}

Sumber : data primer yang diolah

Diketahui bahwa sebagian besar 15 atau (60\%) siswa setuju harus saling menghargai dan menghormati sesama teman, sedangkan 10 atau (40\%) siswa sangat setuju harus saling menghargai dan menghormati sesama teman. 
Siswa diwajibkan untuk menghormati Bapak/ Ibu guru

\begin{tabular}{|c|l|c|c|}
\hline Skor & \multicolumn{1}{|c|}{ Kategori } & Frekuensi (orang) & Persentase (\%) \\
\hline 4 & Sangat setuju & 13 & $52 \%$ \\
\hline 3 & Setuju & 12 & $48 \%$ \\
\hline 2 & Tidak setuju & 0 & $0 \%$ \\
\hline 1 & Sangat tidak setuju & 0 & $0 \%$ \\
\hline & Total & $\mathbf{2 5}$ & $100 \%$ \\
\hline
\end{tabular}

Sumber : data primer yang diolah

\section{Nilai Cinta damai}

Siswa harus menciptakan suasana kelas yang nyaman dan tentram

\begin{tabular}{|c|l|c|c|}
\hline Skor & \multicolumn{1}{|c|}{ Kategori } & Frekuensi (orang) & Persentase (\%) \\
\hline 4 & Sangat setuju & 11 & $44 \%$ \\
\hline 3 & Setuju & 14 & $56 \%$ \\
\hline 2 & Tidak setuju & 0 & $0 \%$ \\
\hline 1 & Sangat tidak setuju & 0 & $0 \%$ \\
\hline & Total & $\mathbf{2 5}$ & $100 \%$ \\
\hline
\end{tabular}

Sumber : data primer yang diolah

Diketahui bahwa sebagian besar 14 atau (56\%) siswa setuju untuk menciptakan suasana kelas yang nyaman dan tentram. Siswa harus mampu mendorong terciptanya harmonisasi di sekolah

\begin{tabular}{|c|l|c|c|}
\hline Skor & \multicolumn{1}{|c|}{ Kategori } & Frekuensi (orang) & Persentase (\%) \\
\hline 4 & Sangat setuju & 6 & $24 \%$ \\
\hline 3 & Setuju & 19 & $76 \%$ \\
\hline 2 & Tidak setuju & 0 & $0 \%$ \\
\hline 1 & Sangt tidak setuju & 0 & $0 \%$ \\
\hline & Total & $\mathbf{2 5}$ & $100 \%$ \\
\hline
\end{tabular}

Sumber : data primer yang diolah

Diketahui bahwa sebagian besar 19 atau (76\%) siswa setuju harus mampu mendorong terciptanya harmonisasi di sekolah, sedangkan 6 atau (24\%) siswa sangat setuju harus mampu mendorong terciptanya harmonisasi di sekolah.

\section{Nilai Gemar membaca}

Siswa harus membiasakan diri untuk gemar membaca

\begin{tabular}{|c|l|c|c|}
\hline Skor & \multicolumn{1}{|c|}{ Kategori } & Frekuensi (orang) & Persentase (\%) \\
\hline 4 & Sangat setuju & 6 & $24 \%$ \\
\hline 3 & Setuju & 19 & $76 \%$ \\
\hline 2 & Tidak setuju & 0 & $0 \%$ \\
\hline 1 & Sangat tidak setuju & 0 & $0 \%$ \\
\hline & Total & $\mathbf{2 5}$ & $100 \%$ \\
\hline
\end{tabular}

Sumber : data primer yang diolah 
Diketahui bahwa sebagian besar 19 atau (76\%) siswa setuju siswa harus membiasakan diri untuk gemar membaca.

Siswa harus belajar dengan sumber bacaan atau referensi yang mendukung

\begin{tabular}{|c|l|c|c|}
\hline Skor & \multicolumn{1}{|c|}{ Kategori } & Frekuensi (orang) & Persentase (\%) \\
\hline 4 & Sangat setuju & 11 & $44 \%$ \\
\hline 3 & Setuju & 14 & $56 \%$ \\
\hline 2 & Tidak setuju & 0 & $0 \%$ \\
\hline 1 & Sangat tidak setuju & 0 & $0 \%$ \\
\hline & Total & $\mathbf{2 5}$ & $100 \%$ \\
\hline
\end{tabular}

Sumber : data primer yang diolah

Berdasarkan tabel 92 dapat diketahui bahwa sebagian besar 14 atau (56\%) siswa setuju setuju siswa harus belajar dengan sumber bacaan atau referensi yang mendukung, sedangkan 11 atau (44\%) siswa sangat setuju untuk belajar dengan sumber bacaan atau referensi yang mendukung.

\section{Nilai Peduli lingkungan}

Siswa harus ikut serta menjaga lingkungan kelas dan sekolah

\begin{tabular}{|c|l|c|c|}
\hline Skor & \multicolumn{1}{|c|}{ Kategori } & Frekuensi (orang) & Persentase (\%) \\
\hline 4 & Sangat setuju & 6 & $24 \%$ \\
\hline 3 & Setuju & 19 & $76 \%$ \\
\hline 2 & Tidak setuju & 0 & $0 \%$ \\
\hline 1 & Sangat tidak setuju & 0 & $0 \%$ \\
\hline & Total & $\mathbf{2 5}$ & $100 \%$ \\
\hline
\end{tabular}

Sumber : data primer yang diolah

Diketahui bahwa sebagian besar 19 atau (76\%) siswa setuju untuk ikut serta menjaga lingkungan kelas dan sekolah.

Siswa harus ikut memelihara tumbuhan dengan baik tanpa menginjak atau merusaknya

\begin{tabular}{|c|l|c|c|}
\hline Skor & \multicolumn{1}{|c|}{ Kategori } & Frekuensi (orang) & Persentase (\%) \\
\hline 4 & Sangat setuju & 11 & $44 \%$ \\
\hline 3 & Setuju & 14 & $56 \%$ \\
\hline 2 & Tidak setuju & 0 & $0 \%$ \\
\hline 1 & Sangat tidak setuju & 0 & $0 \%$ \\
\hline & Total & $\mathbf{2 5}$ & $100 \%$ \\
\hline
\end{tabular}

Sumber : data primer yang diolah

Diketahui bahwa sebagian besar 14 atau (56\%) siswa setuju untuk ikut memelihara tumbuhan dengan baik tanpa menginjak atau merusaknya, sedangkan 11 atau (44\%) siswa sangat setuju untuk ikut memelihara tumbuhan dengan baik tanpa menginjak atau merusaknya. 


\begin{tabular}{|c|l|c|c|}
\hline Skor & \multicolumn{1}{|c|}{ Kategori } & Frekuensi (orang) & Persentase (\%) \\
\hline 4 & Sangat setuju & 7 & $28 \%$ \\
\hline 3 & Setuju & 18 & $72 \%$ \\
\hline 2 & Tidak setuju & 0 & $0 \%$ \\
\hline 1 & Sangat tidak setuju & 0 & $0 \%$ \\
\hline & Total & $\mathbf{2 5}$ & $100 \%$ \\
\hline
\end{tabular}

Sumber : data primer yang diolah

Diketahui bahwa sebagian besar 18 atau (72\%) siswa setuju untuk membuang sampah organik dan sampah non organik di tempat yang sudah disediakan.

\section{Nilai Peduli Sosial}

Siswa harus ikut melakukan kegiatan bakti sosial di sekolah

\begin{tabular}{|c|l|c|c|}
\hline Skor & \multicolumn{1}{|c|}{ Kategori } & Frekuensi (orang) & Persentase (\%) \\
\hline 4 & Sangat setuju & 9 & $36 \%$ \\
\hline 3 & Setuju & 16 & $64 \%$ \\
\hline 2 & Tidak setuju & 0 & $0 \%$ \\
\hline 1 & Sangat tidak setuju & 0 & $0 \%$ \\
\hline & Total & $\mathbf{2 5}$ & $100 \%$ \\
\hline
\end{tabular}

Sumber : data primer yang diolah

Diketahui bahwa sebagian besar 16 atau (64\%) siswa setuju ikut melakukan kegiatan bakti sosial di sekolah.

Siswa ikut serta memberikan bantuan kepada lingkungan masyarakat kurang mampu

\begin{tabular}{|c|l|c|c|}
\hline Skor & \multicolumn{1}{|c|}{ Kategori } & Frekuensi (orang) & Persentase (\%) \\
\hline 4 & Sangat setuju & 10 & $40 \%$ \\
\hline 3 & Setuju & 15 & $60 \%$ \\
\hline 2 & Tidak setuju & 0 & $0 \%$ \\
\hline 1 & Sangat tidak setuju & 0 & $0 \%$ \\
\hline & Total & $\mathbf{2 5}$ & $100 \%$ \\
\hline
\end{tabular}

Sumber : data primer yang diolah

Diketahui bahwa sebagian besar 15 atau (60\%) siswa setuju untuk memberikan bantuan kepada lingkungan masyarakat kurang mampu, sedangkan 10 atau (40\%) siswa sangat setuju untuk memberikan bantuan kepada lingkungan masyarakat kurang mampu.

18. Nilai Tanggung jawab

Siswa diwajibkan mengerjakan tugas dan pekerjaan rumah dengan baik

\begin{tabular}{|c|l|c|c|}
\hline Skor & \multicolumn{1}{|c|}{ Kategori } & Frekuensi (orang) & Persentase (\%) \\
\hline 4 & Sangat setuju & 4 & $16 \%$ \\
\hline 3 & Setuju & 21 & $84 \%$ \\
\hline 2 & Tidak setuju & 0 & $0 \%$ \\
\hline 1 & Sangat tidak setuju & 0 & $0 \%$ \\
\hline & Total & $\mathbf{2 5}$ & $100 \%$ \\
\hline
\end{tabular}

Sumber : data primer yang diolah 
Diketahui bahwa sebagian besar 21 atau (84\%) siswa setuju untuk wajib mengerjakan tugas dan pekerjaan rumah dengan baik, sedangkan 4 atau (16\%) siswa sangat setuju untuk wajib mengerjakan tugas dan pekerjaan rumah dengan baik.

\section{Kesimpulan}

Setelah diadakan penelitian dan pembahasan mengenai pendidikan karakter di Sekolah Dasar Brengosan 1 Ngagglik Sleman, maka dapat diambil kesimpulan sebagai berikut :

1. Upaya yang dilakukan untuk mengembangkan pendidikan karakter di SD N Brengosan yaitu dengan menggunakan bebagai macam cara antara lain Pengajaran karakter, Keteladanan siswa, Pembiasaan/ pembudayaan karakter, Pemotivasian siswa, Penegakan aturan.

2. Hasil yang dicapai adalah pendidikan karakter warga SD N Brengosan 1 ada peningkatan, buktinya religiusitas warga sekolah semakin membaik dengan persentase 64\%, kejujuran peserta didik yang juga mulai terlihat dengan tidak adanya suatu tindakan sebagai contoh mencontek pekerjaan teman yang mencapai 56\%, sikap toleransi 64\%, kedisiplinan 72\%, kerja keras $72 \%$, kreatif $68 \%$, mandiri $68 \%$, demokratis, 64\%, rasa ingin tahu $68 \%$, semangat kebangsaan 64\%, cinta tanah air 64\%, menghargai prestasi 72\%, bersahabat/komunikatif $60 \%$, cinta damai $76 \%$, gemar membaca $76 \%$, peduli lingkungan $76 \%$, peduli sosial $80 \%$, tanggung jawab 84\%, serta prestasi siswa-siswi SD N Brengosan 1 dari tahun ke tahun baik prestasi akademik maupun non akademik.

3. Faktor pendukung pendidikan karakter di SD N Brengosan 1 adalah (a) adanya kerja sama yang baik antara guru dan karyawan, (b) tersedianya fasilitas yang memadai, (c) karena SD $\mathrm{N}$ Brengosan 1 terletak di pemukiman pedesaan. Adapun faktor penghambatnya adalah (a) kurangnya kesadaran peserta didik diatasi dengan mengadakan pelatihan Soft skills, (b) kondisi orang tua, kebiasaan anak dirumah dan lingkungan tempat tinggal sebagian peserta didik yang kurang mendukung, hal ini diatasi dengan menggadakan paguyuban wali murid yang mana dalam paguyuban tersebut wali murid mendapat pengarahan dan bisa berkonsultasi dengan pihak sekolah. 


\section{Daftar Pustaka}

Agus Zainal Fitri (2011) Pendidikan karakter berbasis Nilai dan Etika di Sekolah.

Anton Athoillah (2010), Dasar-dasar Manajemen, Bandung, PT. Pustaka Setia

Agus Wibowo (2013) Manajemen Pendidikan Karakter di Sekolah;Konsep dan Praktik Implementasi, Yogyakarta, PT. Pustaka Pelajar.

Agus Wibowo (2010) Pendidikan karakter Usia Dini. Jakarta.

Arikunto, Suharsimi ( 1997) Prosedur Penelitian, Jakarta, PT. Rineka Cipta.

Dharma Kesuma (2010) Kajian teori dan praktik di sekolah, Bandung, PT. Remaja Rosdakarya.

Direktorat Jendral Manjemen Pendidikan Dasar dan Menegah (2010) Model Pendidikan Karakter di Lingkungan Sekolah.

Hurlock, B.Elizabeth (1978) Perkembangan Anak, Jakarta, PT. Erlangga.

Suwardie (2009) Panduan Penelitian Sosial, Yogyakarta, PT. Amara Books.

M. Furqon Hidayatullah (2010) Pendidikan Karakter; Membangun Peradaban Bangsa, Surakarta, PT. Yuma Pustaka.

Sugihartono ( 2012 ). Psikologi Pendidikan, Universitas Negeri Yogyakarta, Yogyakarta.

Zubaidi (2011) Desain Pendidikan Karakter; Konsepsi dan Aplikasinya dalam Lembaga Pendidikan, Jakarta, PT. Prenada Media Group. 